AGRICA: Journal of Sustainable Dryland Agriculture, 13 (2): 102-116 (2020)

ISSN-Online: 2715-4955; ISSN-Cetak: 2715-6613

DOI: https://doi.org/10.37478/agr.v13i2.746

\title{
PETA PENYEBARAN DAN CITRA FOTO UDARA PENYAKIT TUNGRO PADA TANAMAN PADI DI DESA MARAPOKOT KECAMATAN AESESA KABUPATEN NAGEKEO
}

\author{
Agustinus Mbedo dan Agustinus J.P. Anasaga \\ Program Studi Agroteknologi Fakultas Pertanian Universitas Flores, \\ Jalan Sam Ratulangi XX Paupire Kabupaten Ende, Nusa Tenggara Timur
}

agustinusmbedo8@gmail.com

\begin{abstract}
Map of the distribution and air photo and image of Tungro disease in rice plants in Marpokot Village, AESA district, Nagekeo. The purpose of this study was to determine the spread and aerial photo images of Tungro disease in rice for 2 seasons in Marapokot Village, Kec, Aesesa, Kab, Nagekeo. This research was conducted in Marapokot Village, Aesesa District, Nagekeo Regency which has a rice field area of 12,000 ha (Nagekeo Central Statistics Agency, 2017). The research time was divided into two planting seasons, namely the first planting season was carried out in August 2019 and the second planting season was held in January 2020.The results of this study indicate that the spread of Tungro disease in Marapokot Village, Aesesa District, Nagekeo Regency is spread over seven points with an area of season one 2,238,24m2 while in the second season $1,791,81 \mathrm{~m} 2$ and there is an increase in tungro disease attacks from season one to season two of $36,46 \%$, excessive application of $\mathrm{N}, \mathrm{P}, \mathrm{K}$ fertilizers after planting, monoculture and non-synchronous cropping patterns and poor water management are factors supporting the spread of Tungro disease in Marapokot Village, Aesesa District, Nagekeo Regency.
\end{abstract}

Keywords : Distribution Map, Tungro, Disease

\section{PENDAHULUAN}

Peta adalah suatu representasi atau gambaran unsur-unsur atau kenampakan yang dipilih dari permukan bumi atau benda-benda angkasa dan umumnya digambarkan pada satu bidang datar dan diperkecil dalam ukuran diskala (ICA, 1993 dalam Peratasari, 2015). Pengertian lain tentang pemetaan yaitu sebuah tahapan yang harus dilakukan dalam pembuatan peta yang meliputi pembuatan data, pengolahan data, dan penyajian dalam bentuk peta agar peta tersebut dapat bermanfaat dan dapat digunakan. Menurut Juhadi dan Liesnoor (2001) pemetaan merupakan teknologi penggunaan peta yang sangat menguntungkan dalam melakukan penelitian di area yang luas seperti persawahan agar dapat memantau penyebaranluasan suatu serangan hama atau penyakit. 
Padi (Oryza sativa L.) merupakan komoditi pertanian yang strategis dan menjadi tulang punggung perekonomian di Indonesia karena posisisnya sangat dominan dalam ketahanan pangan sehingga kekuranggan penyedian beras akan menimbulkan dampak bagi kehidupan masyarakat (Fatmawati, 2004). Padi sebagai makanan pangan pokok dikonsumsi kurang lebih $90 \%$ dari penduduk Indonesia. Oleh sebab itu, kebutuhan beras terus meningkat karena peningkatan konsumen tidak diimbangi dengan produksi yang cukup dimana untuk mengimbangi kebutuhan akan beras saat ini pemerintah Indonesia masih melakukan ekspor beras dari negara lainnya.

Kebutuhan padi di Indonesia mencapai 56,54 juta ton sedangkan produksi Nasional baru mencapai 32,42 juta ton. Produksi Nasional pada tahun 2016 dengan luas lahan 8,45 juta hektar yaitu 28,47 juta ton dan produktivitas 18,32 juta ton/ha. Produksi Padi Propinsi NTT pada tahun 2016 dengan luas lahan 200,88 ribu ha produksi 690,82 ribu ton dan produktivitas 80,98 ribu ton/ha (BPS Indonesia 2016). Kabupaten Nagekeo merupakan salah satu Kabupaten penghasil padi di NTT, dansangat berpotensi untuk pengembangan padi dimana pada tahun 2016 luas lahan yang digunakan 3.300 ha dengan rata-rata produksi 529,66 ton/ha (BPS Kabupaten Nagekeo, 2016). Berdasarkan data diatas, terjadi kesenjangan produktivitas padi antara produktivitas Nasional, produktivitas tingkat propinsi dan produktivitas padi ditingkat Kabupaten Nagekeo, ditambah lagi adanya kekurangan kebutuhan padi di tingkat Nasional, maka peluang peningkatan hasil tanaman padi di Kabupaten Nagekeo perlu diupayakan. Belum optimalnya produksi beras di Indonesia karena Salah satu faktor penyebab adanya serangan organisme penganggu tanaman (OPT) baik berupa penyakit maupun hama (Sartono, 2008).

Tungro merupakan salah satu penyakit penting padi yang menjadi kendala dalam peningkatan produksi padi nasional. Tungro disebabkan oleh infeksi dua virus yang berbeda yaitu Tungro Bacilliform Virus (RTBV) dan Rice Tungro Spherical Virus (RTSV), yang keduanya hanya dapat ditularkan oleh wereng hijau (vektor) secara semi persisten peyebaran tungro tidak hanya di Indonesia tetapi juga terjadi di India (Muralidharan et al., 2003, Suranto, 2004), Malaysia, Filipina dan Thailand. Indonesia penyakit tungro di Indonesia 
Mbedo: Peta penyebaran dan citra foto udara penyakit tungro pada tanaman padi

sudah cukup lama dikenal. Gejala utama penyakit tungro tampak pada perubahan warna pada daun muda menjadi kuning orange di mulai dari ujung daun, jumlah anakan berkurang, tanaman kerdil dan pertumbuhannya terhambat. Gejala penyakit tersebar mengelopok, hamparan tanaman padi terlihat seperti bergelombang karena adanya perbedan tinggi tanaman antara tanaman sehat dan terinfeksi (Angeles et al., 2008).

Virus Tungro mulai menyerang tanaman padi di areal persawahan Irigasi Mbay Kanan tepatnya di Desa Aeramo, Kecamatan Aesesa, Kabupaten Nagekeo. Penyakit tungro disebabkan oleh dua jenis virus, yakni virus bentuk batang Rice Tungro bacilliform virus (RTBV) dan virus bentuk bulat Rice Tungro spherical virus (RTSV) ditularkan melalui vector hama wereng hijau (Nephotrttixvirescens) ini akan menghambat pertumbuhan tanaman padi. Menurut Kepala Dinas Pertanian, Tanaman Pangan, Peternakandan Perkebunan Kabupaten Nagekeo, Woifgang Lena mengatakan, hama yang menyerang tanaman padi di Aeramo bukan Tungro tetapi bercak coklat. Indikasi Tungro tersebut diungkapkan pertama kali oleh Matias Ebu Wege, Formulator Bio Urin Plus di Mbay.
Matias yang juga bertugas sebagai penyuluh pertanian di Nangaroro, mengatakan, di areal persawahan Irigasi Mbay saat ini terdapat penyakit tungro dengan gejala serangan sama dengan tanaman yang terserang tungro di daerah luar. Kondisi tersebut diperkuat dengan banyaknya bercak hijau di pertanaman yang merupakan gejala utama dari peyakit tungro. Gejala penyakit tersebar mengelompok dan mengakibatkan penurunan hasil padi yang biasanya 6 ton/ha padi menjadi 3-4 ton/ ha.

Peyebaran virus tungro sangat sulit untuk dipantau, dikarenakan jumlah area yang sangat luas dan diperlukan mengunakan teknologi yang memudahkan manusia untuk mendapat informasi secara cepat dan terpercaya. Dalam bidang pemetaan citra satelit Landsat ETM+ path row 64 digunakan perekaman data untuk mendapatkan informasi spesial berupa foto satelit. Salah satu cara untuk mendapatkan informasi spasial berupa foto udara adalah dengan menggunakan sebuah satelit fotogrametri. Memungkinkan untuk melakuakan pelacakan posisi dan orientasi dari sensor yang diimplementasikan dalam sistem lokal atau koordinat global yang ditentukan 
menggunakan titik kordinat dan musim tanam kedua dilaksanakan menggunakan GPS (Eisenbeiss, 2008).

Boskosar dan Wahyuni (2019) telah menggunakan teknologi GPS untuk membuat foto citra udara dalam memperlihatkan adanya perubahan atau penambahan luas area peyebaran Tungro dimana dalam penelitiannya digunakan pada musim tanam padi kesatu dan pada musim tanam padi kedua yang memperlihatkan hasil serangan dari virus Tungro rata-rata $90,87 \%$ dan dalam metode ini juga akan digunakan untuk pemanfatan perluasan peyebaran peyakit Tungro.

Berdasarkan uraian diatas maka peneliti merasa tertarik melakukan penalitian dengan judul "Peta Penyebaran Penyakit Tungro Pada Tanaman Padi di Kecamatan Aesesa, Desa Marapokot, Kabupaten Nagekeo.

\section{METODE PENELITIAN}

\section{Tempat dan Waktu Penelitian}

Lokasi Penelitian dilaksanakan di Desa Marapokot, Kecamatan Aesesa, Kabupaten Nagekeo yang mempunyai luas lahan sawah mencapai 12.000 ha (Badan Pusat Stasistik Nagekeo, 2017). Waktu penelitian dibagi dua musim tanam yaitu musim tanam pertama dilaksanakan pada bulan Agustus 2019

pada bulan Januari 2020.

\section{Alat dan Bahan}

Alat yang digunakan dalam penelitian ini antara lain GPS untuk menentukan titik kordinat dalam bedengan sawah, citra satelit menampilkan luasan lahan pada tempat serangan tugro, pengkur $\mathrm{pH}$ tanah dan thermohygro untuk mengukur suhu dan kelembaban.

Bahan yang digunakan dalam penelitian ini antara lain alat tulis, buku mistar, pensil untuk menulis bagian data sebagai bantuan dari alat-alat yang digunakan.

\section{Pelaksanaan Penelitian}

Pelaksanaan penelitian dapat dijabarkan sebagai berikut :

1. Persiapan: Meyiapkan alat yang digunakan dalam melakuakan penelitian. Mencakup survei lokasi (gejala, lusan dan topogafi)

2. Perencanan GPS: Perencanan Global Position System untuk menentukan luas area dan titik kordinat berdasarkan hasil survei.

3. Penentuan titik kordinat: Tahap penentuan titik koordinat dilakukan dengan melihat terlebih dahulu lokasi sebaran tungro dan melakukan trecking untuk 
Mbedo: Peta penyebaran dan citra foto udara penyakit tungro pada tanaman padi

menentukan lokasi titik kordinat pada bedengan sawah yang terkena Virus Tungro.

4. Perencanan GCP: Perencanan ini untuk mengukur ground control points atau titik yang terdapat dilapangan dan melakukan trecking untuk mengetahui luasan peyebaran peyakit Tungro dan dapat diidentifikasikan pada foto dan mempunya titik koordinat.

5. Pemetaan atau citra foto satelit: Pemanfaatan citra foto satelit untuk mendapat data foto objek kawasan atau areal penelitian yang dilakuakan sebagai tempat penelitian.

\section{Variabel Pengamatan}

1. Titik Koordinat

Menentukan titik koordinat menggunakan GPS serangan Virus Tungro pada 2 musim tanam dimana pada musim 1 di lakukan pada bulan Agustus 2019 dan sementara pada musim tanam ke 2 di lakukan pada bulan Januari 2020 di Desa Marapokot, Kecamatan Aesesa, Kabupaten Nagekeo.

2. Sebaran Luasan

Menentukan luasan serangan menggunakan GPS untuk menggetahui sebaran Virus Tungro dengan melakukan tracking pada 2 musim tanam dimana pada musim 1 di lakukan pada bulan Agustus 2019 dan sementara pada musim tanam ke 2 di lakukan pada bulan Januari 2020 di Desa Marapokot, Kecamatan Aesesa, Kabupaten Nagekeo. 3. Suhu dan Kelemban Udara

Mengukur suhu dan kelemban pada areal sawah menggunakan alat digital hygrometer yang terserang Virus Tungro pada 2 musim dimana pada musim 1 dilakukan pada pagi hari yang berkisaran jam 08:00-10:30 dan pengukuran di lakukan dalam 7 kali pada bulan Agustus 2019 sementara pada musim ke 2 pada bulan Januari 2020 di Desa Marapokot, Kecamatan Aesesa, Kabupaten Nagekeo.

4. pH dan Kelembapan Tanah

Mengukur $\mathrm{pH}$ dan kelemban tanah pada area sawah menggunakan alat ukur soil $\mathrm{pH}$ tanah yang terserang Virus Tungro pada 2 musim tanam dimana pada musim 1 dilakukan pada pagi hari yang berkisaran jam 08:00-10:30 pagi dan dilakukan pada bulan Agustus 2019 sementara pada musim ke 2 dilakukan pada bulan Januari 2020 di Desa Marapokot, Kecamatan Aesesa, Kabupaten Nagekeo.

5. Citra foto satelit Penyakit Tungro

Mengambil gambaran Penyebaran Virus Tungro menggunakan google 
earth pada 2 musim tanam di Desa Marapokot, Kecamatan Aesesa, Kabupaten Nagekeo.

\section{Luaran Penelitian}

Luaran penelitian ini adalah citra penyebaran penyakit tungro pada 2 musim tanam di Desa Marapokot, Kecamatan Aesesa, Kabupaten Nagekeo. Data analisis yang digunakan dalam penelitian ini adalah analisis deskriptif.

\section{HASIL DAN PEMBAHASAN}

Hasil pengamatan memperlihatkan bahwa penyakit Tungro menyebar pada tujuh (7) titik di desa Marapokot, Kecamatan Aesesa, Kabupaten Nagekeo. Pengamatan diambil pada dua musim tanam dengan rata-rata serangan penyakit virus tungro $36,46 \%$.

Penyebaran penyakit Tungro dikarenakan ketersediaan sumber inokulasi atau tanaman terserang dimana pola tanam yang diterapkan sepanjang tahun adalah monokultur padi. Kondisis ini memungkinkan vektor penular (wereng hijau) akan selalu ada di pertanaman. Fenomena tersebut di perkuat oleh (Hibino dan Cabunagan, 1996) yang menyatakan bahwa gejala penyakit Tungro yang berat disebabkan oleh infeksi dua partikel Virus Tungro berbentuk batang (rice tungro bacilliform virus: RTBV) dan Virus
Tungro berbentuk bulat (rice tungro sphericalvirus: RTSV) fluktuasi insidensi Tungro berkoleransi positif dengan fluktuasi kepadatan populasi vektor apabila tesedia sumber inokulum. Selain tidak terputusnya siklus hidup wereng hijau, kondisi lain yang memperparah terjadinya perluasan area penyebaran penyakit Tungro adalah siklus hidup wereng hijau yang pendek dengan kemampuan makan yang cepat sehingga mempercepat terjadinya penyebaran virus Tungro. Berikut ini sajian peta lokasi penyebaran virus Tungro di Desa Marapokot, Kecamatan Aesesa, Kabupaten Nagekeo.

Pada Gambar 1 luas area penyebaran virus Tungro seluas 2.238,24 $\mathrm{m}^{2}$ pada musim pertama ini area persawahan yang dikerjakan masih utuh dikarenakan perairan irigasi yang digunakan belum diperbaiki karena anakan parit yang digunakan pada musim tanam pertama masih menggunakan anakan parit galian tanah, sementara itu pada Gambar 2 luas area penyebaran virus Tungro $1.791 .81 \mathrm{~m}^{2}$ area persawahan yang dikerjakan hanya setengah dari luas area pada musim satu dikarenakan adanya pekerjan perbaikan irigasi namun demikian penyebaran dari virus Tungro pada musim kedua telah 
Mbedo: Peta penyebaran dan citra foto udara penyakit tungro pada tanaman padi

memasuki musim hujan dimana akan penyakit Tungro Prayogo (2005) dimana mempengaruhi kecepatan penyebaran perkembangan Virus Tungro sangat yang dibantu oleh air merupakan salah tinggi dan petani mengalami kerugian. satu media bantuan dalam penyebaran

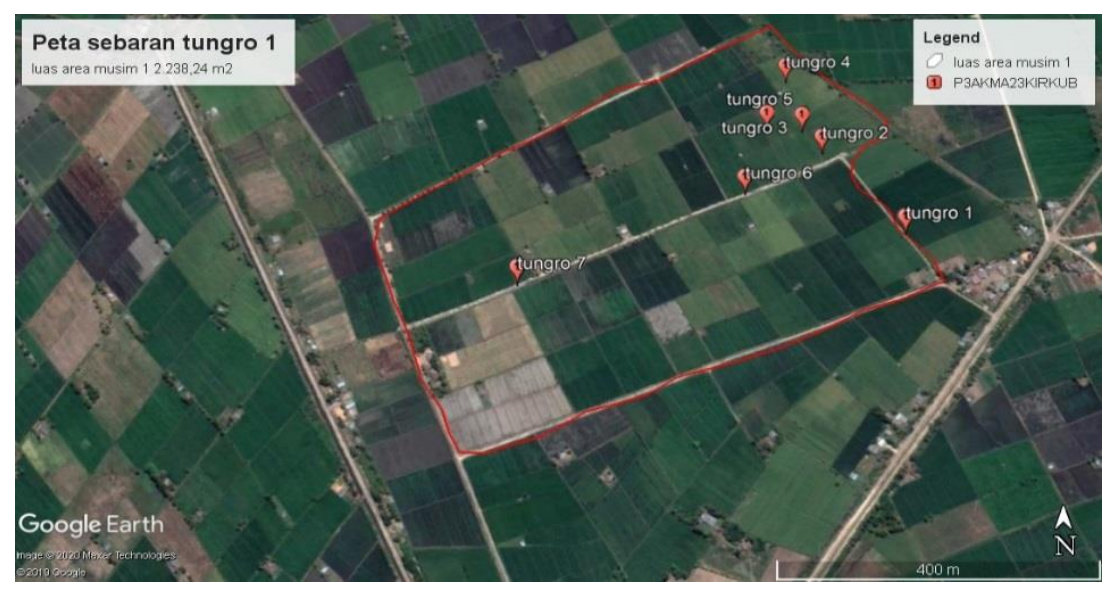

Gambar 1. Peta penyebaran Virus Tungro pada musim tanam 1 yang memiliki tujuh titik kordinat dan memiliki luas area sebesar $2.238,24 \mathrm{~m}^{2}$.

: Gambar merah Merupakan Penyebaran virus tungro

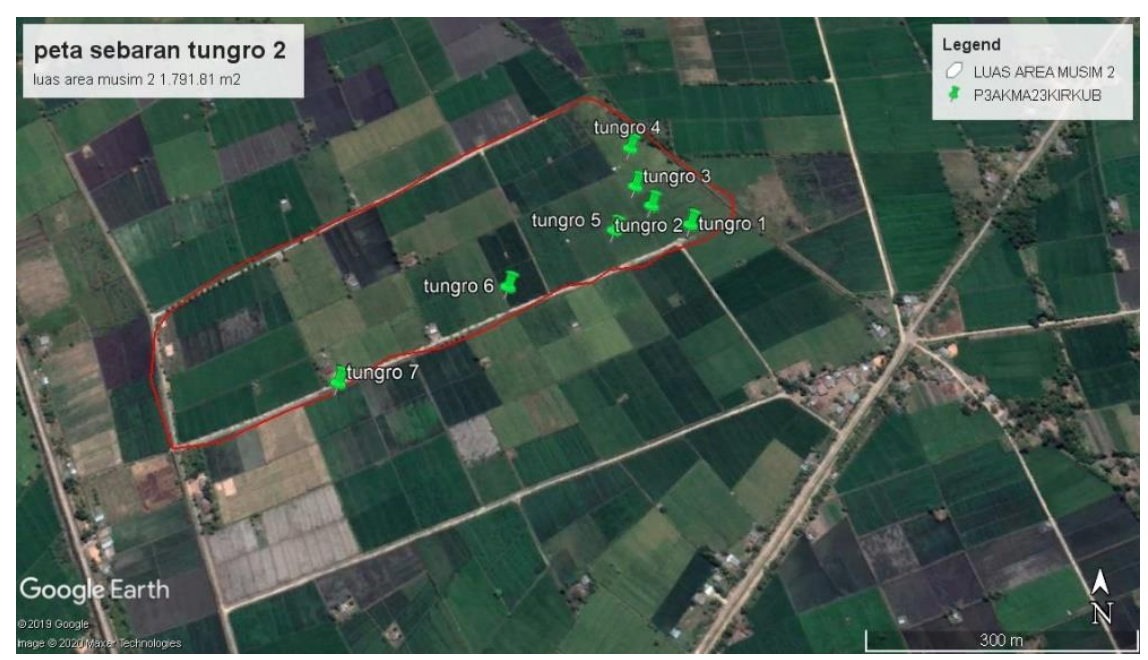

Gambar 2. Peta penyebaran Virus Tungro pada musim tanam 2 yang memiliki tujuh titik kordinat dan memiliki luas area sebesar $1.791 .81 \mathrm{~m}^{2}$.

: Gambar merah Merupakan Penyebaran virus tungro

Secara jelas latitude, logitude, dan Kabupaten Nagekeo di sajikan dalam altitude sebaran penyakit tungro di Desa Tabel 1.

Marapokot, Kecamatan Aesesa, 
Tabel 1. Sebaran penyakit tungro pada musim 1 di Desa Marapokot, Kecamatan Aesesa, Kabupaten Nagekeo.

\begin{tabular}{|c|c|c|c|}
\hline No sampel & Latitude & Longitude & Altitude \\
\hline 1 & $8^{0} 31^{\prime} 59,29$ ' S & $121^{0} 18^{\prime} 28,06^{\prime \prime} \mathrm{E}$ & $-22 \mathrm{M}$ \\
\hline 2 & $8^{0} 31^{\prime} 55,19$ " S & $121^{0} 18,24,62 " \mathrm{E}$ & $-25 \mathrm{M}$ \\
\hline 3 & $8^{0} 31^{\prime} 54,04 " \mathrm{~S}$ & $121^{0} 18^{\prime} 23,79^{\prime \prime} \mathrm{E}$ & $-26 M$ \\
\hline 4 & $8^{0} 31^{\prime} 51,39 " \mathrm{~S}$ & $121^{0} 18^{\prime} 23,19 " \mathrm{E}$ & $-25 \mathrm{M}$ \\
\hline 5 & $8^{0} 31^{\prime} 53,95 " \mathrm{~S}$ & $121^{0} 18^{\prime} 22,18^{\prime \prime} \mathrm{E}$ & $-28 \mathrm{M}$ \\
\hline 6 & $8^{0} 31^{\prime} 57,29 " \mathrm{~S}$ & $121^{0} 18 ' 21,02 " \mathrm{E}$ & $-26 \mathrm{M}$ \\
\hline 7 & $8^{0} 32,1,81 " \mathrm{~S}$ & $121^{0} 18^{\prime} 10,85^{\prime \prime} \mathrm{E}$ & $-23 M$ \\
\hline
\end{tabular}

\section{Suhu dan Kelembaban}

Hasil pengamatan di setiap lokasi terserang penyakit Tungro mengalami perubahan suhu dan kelembaban pada setiap petakan sawah dengan luas lahan $100 \times 100$ dan memiliki jarak tanam 25 $\mathrm{cm}$, rata- rata peningkatan serangan penyakit Tungro dipengaruhi oleh suhu dan kelembaban yang dapat disebabkan karena pola tanam yang tidak serempak, sehingga tersedia makanan bagi vector secara terus menerus, suhu optimum perkembangan Virus Tungro adalah 20 ${ }^{0} \mathrm{C}-30{ }^{0} \mathrm{C}$ kondisi ini disesuaikan dengan keadan suhu dan kelembaban pada dua musim tanam yang dimana pada musim 1 dengan suhu harian ratarata $33,93{ }^{0} \mathrm{C}$ dan pada musim 1 kelembaban harian rata-rata $63 \%$ sementara pada musim 2 perkembangan virus tungro yang memiliki suhu harian memiliki rata-rata $33,60{ }^{0} \mathrm{C}$ dan sementara pada musim 2 kelembaban harian memiliki rata-rata 59\% tersebut merupakan keadaan ideal untuk memberi peluang berkembangnya penyakit Tungro (Pakki, 2011). Mengakibatkan perkembangan virus tungro sangatlah cepat yang dapat merugikan para petani dan dapat disajikan dengan Tabel 2.

Tabel 2. Suhu dan kelembaban udara pada bedengan sawah di Desa Marapokot, Kecamatan Aesesa, Kabupaten Nagekeo.

\begin{tabular}{lcccc}
\hline No & $\begin{array}{c}\text { Rata-rata } \\
\text { suhu musim 1 } \\
\left({ }^{\mathbf{0}} \mathbf{C}\right)\end{array}$ & $\begin{array}{c}\text { Rata-rata } \\
\text { suhu musim 2 } \\
\left({ }^{\mathbf{0}} \mathbf{C}\right)\end{array}$ & $\begin{array}{c}\text { Rata-rata } \\
\text { kelembaban } \\
(\boldsymbol{\%}) \text { musim } \mathbf{1}\end{array}$ & $\begin{array}{c}\text { Rata-rata } \\
\text { kelembaban } \\
(\boldsymbol{\%}) \text { musim 2 }\end{array}$ \\
\hline Titik 1 & 32,12 & 32,20 & 71 & 55 \\
Titik 2 & 35,62 & 33,28 & 61 & 54 \\
Titik 3 & 34,27 & 34,20 & 58 & 61 \\
Titik 4 & 35,35 & 33,62 & 55 & 62 \\
Titik 5 & 33,27 & 30,35 & 61 & 60 \\
Titik 6 & 31,20 & 36,24 & 62 & 63 \\
Titik 7 & 35,68 & 35,28 & 73 & 58 \\
\hline
\end{tabular}


Mbedo: Peta penyebaran dan citra foto udara penyakit tungro pada tanaman padi

\section{pH Tanah dan Suhu Tanah}

Hasil pengamatan di setiap lokasi terserang penyakit tungro mengalami perubahan $\mathrm{pH}$ dan Suhu tanah pada setiap petakan sawah yang teserang penyakit Tungro pada musim 1 ukuran $\mathrm{pH}$ tanah yang memiliki rata-rata sekitar $3,83 \mathrm{pH}$ pada suhu tanah berkisar 27.15 ${ }^{0} \mathrm{C}$ dan sementara pada musim ke 2 perubahan $\mathrm{pH}$ dan suhu tanah yang memiliki rata-rata sekitar 4,26 $\mathrm{pH}$ pada suhu tanah berkisar $27.29{ }^{0} \mathrm{C}$ menurunnya kualitas tanah pada petakan sawah mengakibatkan rendahnya $\mathrm{pH}$ tanah dan suhu tanah yang dapat mengakibatkan tanaman mudah terserang penyakit Tungro. Pemberian nitrogen yang berlebihan pada padi sawah dapat meningkatkan kerusakan tanaman, dan mudah terserang hama penyakit pada tanaman padi (Suranto
2004). Menjelaskan bahwa menurun dan meningkatnya kualitas $\mathrm{pH}$ dapat mempengaruhi serapan pupuk yang diberikan seperti N, P dan K, bisa saja hilang dikarenakan pemberian pupuk urea yang berlebihan dan dapat menyebabkan turunnya $\mathrm{pH}$ tanah sehinga mikro flora dan fauna mati, tanah menjadi padat, dan tata erasi menjadi jelek yang akhirnya menghambat perkembangan akar dan pertumbuhan tanaman. Angeles et al. (2008) Menjelaskan bahwa tanaman yang belum dapat berkembang secara optimal atau dapat dikategorikan kondisi pada tanaman kurang sehat yang selanjutnya akan menyebabkan tanaman rentah terhadap serangan hama dan penyakit tanaman. Pernyatan ini terlihat dari hasil analisis $\mathrm{pH}$ tanah dan suhu tanah pada Tabel 3.

Tabel 3. Suhu tanah dan $\mathrm{pH}$ tanah pada bedengan sawah di Desa Marapokot, Kecamatan Aesesa, Kabupaten Nagekeo.

\begin{tabular}{ccccc}
\hline No & $\begin{array}{c}\text { pH tanah } \\
\text { musim 1 }\end{array}$ & $\begin{array}{c}\text { Suhu tanah }\left({ }^{\circ} \mathbf{C}\right) \\
\text { musim 1 }\end{array}$ & $\begin{array}{c}\mathbf{p H} \text { tanah } \\
\text { musim 2 }\end{array}$ & $\begin{array}{c}\text { Suhu tanah }\left({ }^{\circ} \mathbf{C}\right) \\
\text { musim 2 }\end{array}$ \\
\hline Titik 1 & 4,3 & 26 & 4,5 & 26 \\
Titik 2 & 4,5 & 27 & 5,5 & 27 \\
Titik 3 & 4,1 & 28 & 4,0 & 28 \\
Titik 4 & 3,4 & 26 & 3,5 & 27 \\
Titik 5 & 3,5 & 28 & 5,0 & 27 \\
Titik 6 & 4,2 & 28 & 4,5 & 28 \\
Titik 7 & 2,8 & 27 & 2,8 & 28 \\
\hline
\end{tabular}




\section{Keberadan Peyakit Tungro}

Hasil pengamatan selama di tempat lokasi terserang penyakit Tungro dengan gejala berubah daun berwarna kuning dan terlambat berkembang serta berbunga (Gambar 3).

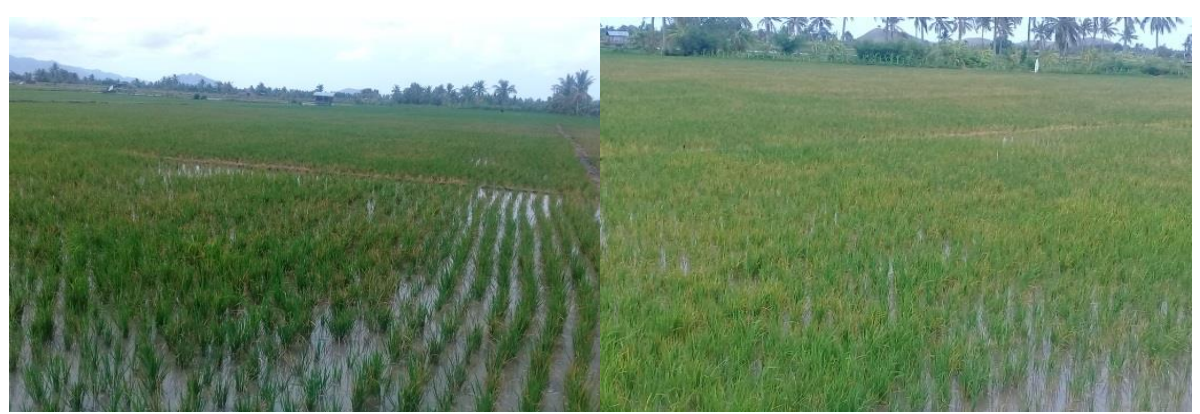

Gambar 3. Padi yang terkena gejala penyakit tungro

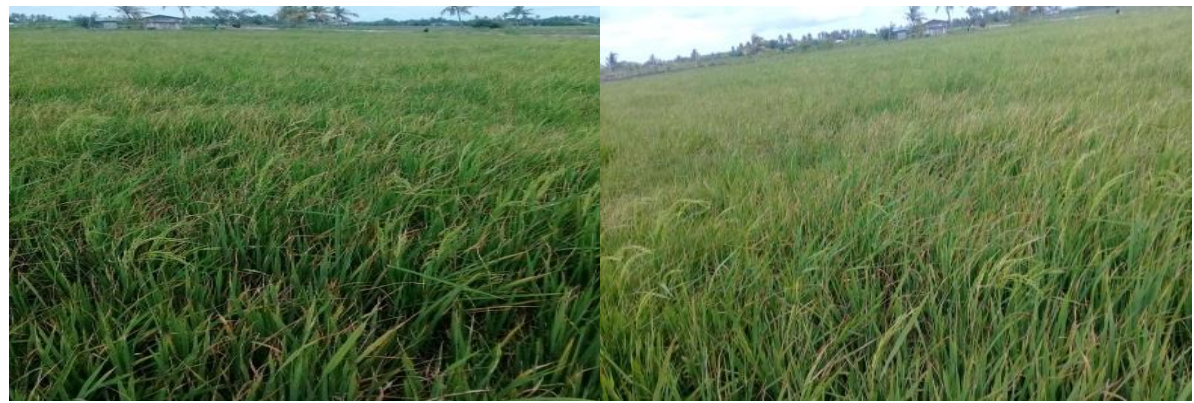

Gambar 4.Rumpun yang terlambat berkembang dan berbunga akibat Virus Tungro

Keberadaan gejala penyakit tungro di lapangan dapat merugikan petani karena kerusakan tanaman padi, anakan berkurang, menghambat proses perkembangan dan pembungaan, memperlambat proses fotosintesis dan kerdil. Tanaman sakit terlambat membentuk bunga (Gambar 3). mulai kecil dan tidak sama sekali keluar dari upih daun, kebanyakan bijinya hampa atau terisi sebagian dan sering mempunyai bercak-bercak coklat tua. Tanaman kurang membentuk akar, tanaman sakit cenderung lebih rentah terhadap bercak coklat (Drechslera Oryzae) dan bercak coklat sempit (Cercospora Janseana) Penyakit Tungro paling luas serangannya dibandingkan penyakit lainnya yang menyerang tanaman padi (Widiarta dan Daradjat, 2000). Menurut Soetarto (2001), ratarata luas serangan tungro setiap tahun mencapai 12.000 ha, bahkan pada saat Outbreak luas serangan di satu provinsi saja bisa mencapai beberapa kali lipat rata-rata luas serangan tahunan nasional. 
Mbedo: Peta penyebaran dan citra foto udara penyakit tungro pada tanaman padi

Keberadaan penyakit Tungro di Desa Marapokot, Kecamatan Aesesa, Kabupaten Nagekeo sudah diketahui oleh para petani namun belum menemukan solusi atau cara untuk mengendalikan penyakit Tungro tersebut. Menurut laporan dari para petani populasi Tungro meningkat pada akhir musim kemarau dan awal musim hujan peningkatan terjadi dikarenakan ukuran suhu dan kelembaban yang terdapat pada 2 musim tanam yaitu pada musim tanam ke satu memiliki ukuran rata-rata suhu $33,93{ }^{0} \mathrm{C}$ dan kelembaban pada petakan sawah memiliki ratra-rata $63 \%$ sementara pada musim tanam kedua memiliki rata-rata suhu $33,60 \%$ dan kelembaban $60,43 \%$. Dalam pengukuran $\mathrm{pH}$ serta suhu tanah yang terdapat pada petakan sawah pada musim 1 memiliki rata-rata $3,8 \mathrm{pH}$ dan ukuran suhu rata-rata $27.15 \quad{ }^{0} \mathrm{C}$ sementara pada musim kedua rata-rata 4,26 $\mathrm{pH}$ dan ukuran suhu rata-rata 27.29 ${ }^{0} \mathrm{C}$. Hasil pengamatan menunjukan bahwa populasi wereng hijau pada musim kemarau lebih rendah dari pada musim hujan dikarenakan pada musim kemarau suhu udara pada bedengan sawah sangat panas yang mengakibatkan perkembangan virus Tungro sangat lambat (Carino, 1990). Pola flukltuasi populasi wereng hijau dan keberadaan Tungro di kebun percobaan lokal tungro lanrang, Sulawesi selatan menujukan adanya dua puncak populasi wereng hijau yang terjadi dalam satu tahun dan kepadatan populasi pada musim kemarau (akhir Agustus) lebih rendah dari pada musim hujan (April). Faktor iklim terutama suhu berpengaruh terhadap daur hidup wereng hijau, pemerolehan virus dan penularan virus.

Tabel 4. Jumlah rumpun yang terserang penyakit Tungro di Desa Marapokot, Kecamatan Aesesa, Kabupaten Nagekeo.

\begin{tabular}{cccc}
\hline $\begin{array}{c}\text { No } \\
\text { Sampel }\end{array}$ & $\begin{array}{c}\text { Rumpun } \\
\text { musim 1 }\end{array}$ & $\begin{array}{c}\text { Rumpun } \\
\text { musim 2 }\end{array}$ & $\begin{array}{c}\text { Presentasi penyakit Tungro terhadap } \\
\text { rumpun yang terserang }(\%)\end{array}$ \\
\hline 1 & 24 & 160 & 85,00 \\
2 & 45 & 85 & 47,05 \\
3 & 60 & 120 & 50,00 \\
4 & 90 & 110 & 18,18 \\
5 & 50 & 75 & 33,33 \\
6 & 30 & 95 & 36,84 \\
7 & 120 & 260 & 53,85 \\
\hline
\end{tabular}


Pada Tabel 4 dapat dilihat jumlah yang paling banyak terserang pada dua musim tanam terdapat pada titik koordinat yang ke satu yaitu $85 \%$ dan yang terendah terdapat pada titik koordinat yang ke empat yaitu 18,18\% .

Seperti yang ditunjukan pada Tabel 4 bahwa pada titik satu populasi Tungro pada dua musim tanam meningkat sampai $85 \%$ peningkatan ini terjadi karena vektor yang kemampuan makan cepat sehingga mempercepat terjadi penyebaran penyakit Tungro. Populasi penyebaran penyakit Tungro yang paling rendah terdapat pada titik keempat yaitu $18,18 \%$. Pada titik keempat musim tanam pertama dan kedua bedengan sawah mengalami penurunan penyebaran Virus Tungro dikarenakan pada titik keempat petani menggunakan petisida dan membersihkan gulma yang terdapat pada petakan sawah, sehingga wereng hijau yang terdapat pada lokasi ini tidak lagi mempunyai sumber inokulasi (tanaman terserang) cara ini membuahkan hasil karena populasi Tungro pada musim tanam pertama dan kedua pada lokasi ini menurun. Sistem pengendalian penyakit Tungro secara terpadu dengan mengusahakan agar tanaman terhindar dari penyakit Tungro dengan memadukan komponen teknologi, seperti waktu tanam tepat, pergiliran varietas tahan wereng hijau, dan penggunaan insektisida secara bijaksana (Sama et al., 1991) yang menyatakan bahwa upaya-upaya yang di lakukan petani untuk mengantisipasi terhadap peningkatan serangan virus Tungro yaitu berupa pengendalian kuaritif. Di Jawa Timur dalam tahun 2006 seluas 3,392,23 ha dengan perincian: pemusnahan seluas 325,61 ha, aplikasi petisida seluas $2.865,98$ ha dan cara lain seluas $1,616,25$ ha. Menurut Muralidharan et al. (2003) untuk mengendalikan penyakit Tungro perlu di lakukan yang pertama dengan menggunakan bibit unggul, pembersihan gulma dan menggunakan pestisida untuk mengendalikan sebaran virus Tungro merupakan cara terbaik untuk mengendalikan Tungro. Rotasi varietas untuk mengurangi gangguan ketahanan, yang kedua mencabut dan membakar tanaman yang sakit, ini di lakukan kecuali bila serangan Tungro sudah menyeluruh. Bila serangan sudah tinggi maka mungkin ada tanaman padi saat populasi wereng hijau Tungro rendah, yang keempat tanaman serempak, upaya petani tanaman serempak ini mengurangi penyebaran tungro dari satu lahan ke lahan yang lain. 
Mbedo: Peta penyebaran dan citra foto udara penyakit tungro pada tanaman padi

Penyebaran penyakit Tungro ini dapat merugikan petani, karena luas area penyebaran penyakit Tungro sangat tinggi yang dapat mengakibatkan kerusakan tanaman padi. Penanaman padi secara monokultur serta pembagian aliran air kurang bagus dan penggunaan pupuk $\mathrm{N}, \mathrm{P}, \mathrm{K}$ yang berlebihan akan menyebabkan kelebihan pada unsur hara tanah. Hal ini membawa dampak buruk bagi penghasilan para petani yang semakin menurun. Di setiap lokasi terserang penyakit Tungro penelitian menemukan vektor (penular) yaitu wereng hijau, selain itu petani tidak menggunakan pola tanam yang serempak. Penamanan yang tidak serempak akan menjamin ketersediaan inang dalam rentah waktu yang panjang bagi perkembangan virus Tungro, sehingga memungkinkan wereng hijau berkembang kerena adanya tanaman peka dan kondisi lingkungan yang memungkinkan (Tandiabang, 2001).

\section{SIMPULAN}

Dari hasil penelitian ini dapat disimpulkan bahwa :

1. Penyebaran penyakit Tungro di Desa Marapokot, Kecamatan Aesesa, Kabupaten Nagekeo tersebar di tujuh titik dengan luasan musim satu 2.238,24 $\mathrm{m}^{2}$ sementara pada musim kedua 1.791,81 $\mathrm{m}^{2}$ dan terjadi peningkatan serangan penyakit tungro dari musim satu ke musim dua sebesar $36,46 \%$

2. Aplikasi pupuk N, P, K yang berlebihan setelah tanam, pola tanam monokultur dan tidak serempak serta manajemen penggaturan air yang tidak baik menjadi faktor pendukung penyebaran penyakit Tungro di Desa Marapokot, Kecamatan Aesesa, Kabupaten Nagekeo.

\section{UCAPAN TERIMAKASIH}

Ucapan terima kasih yang sebesar-besarnya kami ucapkan kepada ibu Dr. Sri Wahyuni, SP., M.Si atas saran dan kritikannya sehingga tulisan ini layak diterbitkan pada Jurnal AGRICA.

\section{DAFTAR PUSTAKA}

Angeles ER, Cabunagan RC, Tabien RE and Khush GS. 2008. Resistance to tungro vectors and viruses. p. 117141. In Tiongco, E.R., E.R. Angeles and L.S. Sebastian (ed.), Rice tungro virus disease: a paradigm in disease management. Science City of Munoz, Nueva Ecija: Philippine Rice Research Institute and Honda Research Institute Japan Co. Ltd., 2008.

$\begin{array}{ccr}\text { Boskosar dan } & \text { Wahyuni } & 2019 . \\ \text { Penggunaan } & \text { GPS } & \text { Untuk } \\ \text { Mendeteksi } & \text { Peyebaran } & \text { Penyakit } \\ \text { Tungro. Tungas Akhir. } & \text { Ende } \\ \text { Sekolah Tinggi Universitas } & \text { Flores }\end{array}$


Ende NTT-Indonesia AGRICA, 12 (1) : 12-22, ISSN : 1979-0368

BPS.2016.Statistik Indonesia. Jakarta. http://jakarta.Badanstastistik.go.id. diakses Tanggal 28 Desember 2019.

BPS.2017.Nagekeo. http://jakarta.Badan stastistik.go.id. diakses Tanggal 12 Desember 2019

Carino, F.O. 1990. Role of natural enemies in population suppression and pest management of the green leat hopper. UPLB. MS.Thesis.

Djojosumarto, P.2000. Teknik Aplikasi Petisida Pertanian. Kanisius. Yokyakarta.

Eisenbeiss.2008. Dalam bidang pemetaan fotogrametri mendapatkan informasi special berupa foto citra satelit. Jakarta. Universitas Indonesia Perss.

Fatmawati.2004. Varietas unggul padi. http://banten.Litbang.deptan.go.id. Tanggal 6 Oktober 2015.

Habibi, Wildan, 2011. Jurnal : Pembangunan Sistem Pelacakan danPenulusuran Device Mobile Berbasis Global Positioning Sistem (GPS)Pada Platform Mobile Google. Institut Teknologi Sepuluh Nopember, Bandung PADA PLATFORM MOBILE GOOGLE. Surabaya. (Januari 2011).

Hibino; Cabuangan 1996. Gejala penyakit tungro menimbulkan infeksi pada tanaman padi yang memliki gejala kerdil. Status dan program penelitian pengendalian Virus Tungro. Yokyakarta.
Permatasari, I. 2015. Aplikasi system informasi geogerafis untuk pemetaan persebaran tempat pendidikan anak usia dini di kabupaten bantul. Tugas akhir. Yoyakarta: sekolah vokasi universitas Gajah Mada.

Juhadi; Liesnoor. 2001. Desain dan Komposisi Peta Tematik. Semarang : Pusat Pengkajian dan pelayanan system informatika Geogerafis UNNES

Muralidharan, K., D. Krishnaveni, N.V.L. Rajarajeswari and A.S.R. Prasad. 2003. Tungro epidemics and yield losses in paddy fields in India. Current Science, 85(8): 1143-1147.

Pakki S., 2011. Variabilitas Penyakit Tungro Pada Beberapa Varietas Unggul Padi Inbrida Di Wilayah Endemis. Seminar dan Pertemuan Tahunan XXI PEI,PFI Komda Sulawesi Seletan dan Dinas Perkebunan Pemerintah Provinsi Sulawesi Selatan tanggal 7 Juni 2011 di Hotel Singgasana Makassar.

Permata S;ICA.1993. Aplikasi system informasi geogerafis untuk pemetaan persebaran tempat pendidikan anak usia dini di kabupaten bantul. Tugas akhir. Yoyakarta: sekolah vokasi universitas Gajah Mada.

Prayogo. 2005. Peyebaran virus tungro yang dibantu oleh media air. Seminar Nasional Status Program Penelitian Tungro Mendukung Keberlanjutan Produksi Padi Nasional.

Sartono J; Indriyati W. 2008. Tanaman terinfeksi Virus Tungro.Status dan 
Mbedo: Peta penyebaran dan citra foto udara penyakit tungro pada tanaman padi

program penelitian pengendalian Virus Tungro. Yokyakarta.

Suranto. 2004. Pengelolaan Virus Tungro Melalui Pendekatan Bioteknologi. Status dan Program Penelitian Pengendalian Terpadu Penyakit Tungro. p. 15-25. In A. Hasanuddin, I.N. Widiarta dan Sunihardi (eds.), Strategi Pengendalian Penyakit Tungro: Status dan Program, Prosiding Seminar Nasional Status Program Penelitian Tungro Mendukung Keberlanjutan Produksi Padi Nasional.

Sutarto. 2001. Rata-rata luasan serangan penyakit tungro. Status dan program penelitian pengendalian Virus Tungro. Yokyakarta.
Tandiabang. 2001. Penyebaran penyakit tungro. Status Dan Program Penelitian Pengendalian Terpadu Penyakit Tungro: Status Dan Program Prosiding Seminar Nasional Status Program Penelitian Tungro Mendukung Keberlanjutan Produksi Padi Nasional.

Widiarta; Daradjat.2000.Penyakit tungro paling luas serangannya dibandingkan penyakit lain.

Wildan Habibi, 2011. GPS menggunakan konstelasi. Bandung Pada Platform Mobile Google. Surabaya. 